Conclusion 



\title{
Taiwan and the Waning Dream of Reunification
}

\author{
Lowell Dittmer
}

China and Taiwan constitute one of the four nations divided by the Cold War. ${ }^{1}$ This division was originally intended to be only temporary, but reunification soon became impossible as the Cold War polarized in the late 1940s and each "half" became embedded in the front lines of its side. This division has proved especially intractable because the international ideological cleavage overlay embittered civil wars-in China, the revolutionary civil war. Yet reunification has been incorporated into the founding visions of national self-realization in China and to some extent in Taiwan.

This concluding chapter focuses on why, after the dream was revived along with the KMT (Kuomintang, or Nationalist Party) victory in 2008, it now seems to be fading. The first part of the chapter outlines the original legitimacy basis for reunification as a national goal. The second critically reviews vicissitudes in the reunification narrative since 1949 . The third attempts to explain the current turn away from reunification.

\section{WHY REUNIFICATION?}

The appeal of national unification is the quest for collective roots, which are to some extent primordial. The Chinese claim to Taiwan is both historical and ethnolinguistic. Some mainland historians claim that Taiwan has been part of China since the beginning of the Sui dynasty (598-618), though official dynastic histories as late as the Ming (1368-1644) make no reference to Taiwan in the section on administrative geography (the dilizhi, which comprehensively lists all provinces, prefectures, subprefectures, and counties of the Ming state), so we may infer it was 
then no more than an outlying frontier region. By the thirteenth century, however, there were a significant number of Chinese settlements on the island, where fertile virgin land and mild climate drew economic migrants. The island also attracted early imperialist interests. (In 1622 the Dutch drove out Spanish settlers and established a colony.) A rebel named Cheng Chenggong (known in the West as Koxinga) established a "pirate" garrison near Tainan in the name of the recently defeated Ming, but the Qing dispatched their navy under Admiral Shi Lang to destroy the Zheng fleet in the Battle of Penghu (1683), thereafter annexing the island as a prefecture of Fujian Province. In 1887 Taiwan finally became an imperial province, only to be annexed by Japan only eight years later, following China's defeat in the Sino-Japanese War. It remained a colony from 1895 to 1945 . The Nationalists, having brutally reestablished Chinese control in $1945-47$, retreated to the island upon losing the civil war on the mainland in 1949 with the declared intention of reversing that outcome at the first opportunity.

For its part, the People's Republic of China (PRC) fully expected to "liberate" the island as soon as they consolidated control of southern China, thereby completing their revolution and ending "one hundred years of humiliation" (bainian guochi) by overthrowing the "unequal treaty" of Shimonoseki that ceded Taiwan to Japan. But Chinese intervention on behalf of the Democratic People's Republic of Korea in the Korean War in November 1950 precipitated US intervention in support of the Nationalists, indefinitely postponing plans to bring the civil war to a conclusion. Ethnically, all but some 2 percent of the populace, both natives (benshengren) and migrants from the mainland (waishengren), are Han Chinese, speak a local dialect of Mandarin, and observe Chinese ceremonial rituals.

Since the unfinished Second Civil War, the goal of unification has been deeply embedded in national identity symbolism on both sides of the Strait. The Chiangs both believed to their dying days in "one China," notoriously declining the chance to retain international diplomatic recognition and membership in the UN General Assembly as an independent Taiwan if that meant renouncing the claim to be part of one China. That claim is written into the constitutions of both the PRC and the Republic of China (ROC), and it endures in the flags, coinage, postage stamps, and history texts of both sides. Taiwan throughout the Chiang dictatorship continued to represent all mainland provinces in the (largely symbolic) National Assembly, just as both the Chinese People's Political Consultative Congress and the National People's Congress included (and still include) delegates nominally representing Taiwan. Taiwanese, whether native benshengren or waishengren, are distinguished from foreigners (waiguoren) on the mainland as "compatriots" (tongbao). Despite recent disenchantment with the dream of reunification, there is a persisting legacy that insistently, recurrently raises the question. Indeed, the spirit of nationalism cannot be evoked on either side without reopening that issue. Ambition for enhanced national power is also relevant: 
a freely united China would be an even more powerful and prestigious presence on the world stage than it already is.

From an international perspective the Taiwan question is a painful diplomatic anomaly. During the Cold War it was an unstable point in the structure of global bipolarity, as exhibited by refugee flows, inflammatory rhetoric, unilateral threats, and red line crossings. And since the Cold War it remains a perennial international flash point that could still spark war between two nuclear powers and suck in surrounding states. Thus the international community (such as it is) would in principle welcome its orderly, peaceful resolution. Since 172 sovereign states (including the United States) have formally acknowledged China's claim that there is one China and that Taiwan is part of China, any objection to such reunification would technically involve them in self-contradiction. Some American allies (e.g., Australia) have even expressed the wish to opt out of their alliance commitments should they involve the China-Taiwan dispute. And, as Ping-Kuei Chen, Scott Kastner, and William Reed note above (chapter 12), some analysts urge the United States to abandon Taiwan in order to facilitate reunification and improve relations with the more strategically relevant PRC. A survey conducted by the Chicago Council on Global Affairs in 2014 showed that only 26 percent of Americans agree with the idea of sending troops to help Taiwan, compared to 47 percent who support South Korea. This result has been very consistent over time with other surveys since 1982. While no one agrees with China's threats to use force in the last resort to achieve reunification, few are prepared to fight if it does.

The fact that the interest in unification is fundamental on both sides of the Strait does not mean that there is agreement on how to get there, who should rule the reunified state, or how it should be organized. Nor does it mean that this interest is evenly distributed. The pattern has been for the side that is more powerful to have the greatest interest in reunification and to be willing to use more forcible means to get it, under the premise that it will continue to dominate the unified state. The weaker side, drawing on the same premise, in contrast has a propensity to demur or procrastinate and to try to prohibit the use of force to achieve unification.

\section{THE PURSUIT OF UNITY}

If the historical legacy and the international balance of power are so overwhelmingly in favor of reunification, what is holding it back? There have been two Taiwanese counterarguments. The first, championed mainly by the Democratic Progressive Party (DPP), is that Taiwan has not been part of China for well over a century, that the democratic government of Taiwan fulfills all the requirements of statehood, and that its independence should consequently be recognized by a name change and a revision of the constitution. The second argument, made mainly by the Nationalist Party or KMT, is that the ROC was established and internationally 
recognized after the Xinhai rebellion in 1911 and that it was never defeated (there has been no armistice or peace treaty) but was driven to take refuge in Taiwan, where it continues to claim sovereignty over the Chinese mainland. Since the late 1990 s the first argument has proved more electorally persuasive on the island but is denounced on the mainland as "splittism." The second argument, reaffirmed by the Ma Ying-jeou regime in 2008, is implicitly accepted by Beijing in the form of the "1992 Consensus", in which each side defines "one China" in its own way.

But this is to get ahead of our story. During the Cold War both "Chinas" expressed a commitment to reunification, and the means by which this was to be achieved were coercive. For the first three decades of Taiwan's existence, while the two respective leaders of the civil war remained at the helm, warlike conditions essentially continued: the Nationalists imposed martial law, invoked anticommunism to legitimate their authoritarian rule and the prosecution of political dissent, and promised to "recover the mainland" (huifu dalu), presumably by force, supplemented (as in the Bay of Pigs) by a popular anticommunist uprising. Beijing precipitated two cross-Strait crises in $1954-55$ and 1958 by threatening an invasion of the offshore islands still occupied by Taiwan and bombarding the islands with deadly artillery, continuing desultory bombardments (mostly propaganda leaflets) until January 1979. Yet neither a Chinese invasion of Taiwan nor a Nationalist invasion of the mainland ever took place. The balance of forces was too strong for the People's Liberation Army (PLA) after formation of the Sino-American security alliance in 1954, and the United States refused to "unleash" a Nationalist invasion of the mainland during the disastrous aftermath of the Great Leap or during the Cultural Revolution. But each side's plans for reunification were zero-sum, premised on elimination of the opposing government. The ROC government represented "China" in the United Nations (including the Security Council) and in most foreign embassies, enforcing a "one-China policy" by breaking diplomatic relations with any country that recognized the PRC. Since replacing Taiwan in the UN in 1971 the PRC has turned the tables, refusing to recognize any state that recognizes Taiwan.

The end of the Cold War, which occurred about two decades earlier in Asia than in Europe thanks to the Nixon-initiated Sino-American détente, opened opportunities for innovative approaches untrammeled by the ideological frameworks and internal alliance networks that had previously anchored the issue to bloc solidarity. Beginning with the advent of "reform and opening" in China and the onset of democracy in Taiwan a decade later, both sides explored new ideas for breaking the deadlock. Promptly after gaining US diplomatic recognition (and derecognition of Taiwan and termination of the Sino-American Alliance), Beijing introduced proposals for "three direct links" across the Strait (travel, trade, and postal) and the slogan "One country, two systems" to describe a form of reunification that would grant a "high degree of autonomy" to Taiwan for a period of fifty 
years. This was Beijing's most generous offer to date, for the first time offering a reasonably attractive option for peaceful unification. The immediate response from Chiang Ching-kuo was "three nos" ("no contact, no compromise, no negotiation"), but the mainland persisted, and before his death Chiang initiated a reciprocal opening to the mainland by permitting retired soldiers to visit their home villages on the mainland. The succeeding Lee Teng-hui regime established a cabinet-level National Unification Council, which in 1991 issued "National Unification Guidelines" that affirmed the ultimate goal of national unification premised on prior agreement to preserve Chinese culture and the achievement of political democracy, economic liberalization, and social pluralism in the PRC.

These offers were mutually incompatible: the Chinese package educed no reason for Taiwan to believe that an otherwise totalitarian government would grant full autonomy to a former enemy, while the Taiwan package imposed demands for transformation of the mainland regime and none for Taiwan. But both offers envisaged peaceful reunification and positive-sum postunification governing arrangements for the first time, opening the way to further discussion. First Taipei and then Beijing set up quasi-official diplomatic organs, the Straits Exchange Foundation (SEF) and the Association for Relations Across the Taiwan Straits (ARATS) respectively, and after secret negotiations in Hong Kong (where what became known as the 1992 Consensus was agreed upon) engaged in a series of meetings in Singapore to discuss further steps to facilitate trade, postal, and other exchanges. Although the "three direct links" remained off the table, trade, indirect investment, and travel grew steadily via Hong Kong.

Meanwhile politics - the intended dependent variable of socioeconomic integration-proceeded erratically, refusing to follow neofunctionalist (or Marxist) logic. Both sides hedged, reflecting continuing distrust: Taiwan engaged in rapprochement with China but tried to match this with equivalent diplomatic steps to the West via "flexible diplomacy" (e.g., dollar diplomacy, vacation diplomacy, and other expedients, none having lasting results); Beijing's hedge was to accompany its pledges of peaceful reunification with a refusal to renounce the use of force and a continuing military buildup on the Fujian coast. Roughly speaking, the period from 1988 to 1995 was one of political "thaw," followed by the 1995-96 missile crisis, which resulted in a "freeze" from 1995 to 2005, followed by another, warmer "thaw" from 2005 to 2015. The pattern was initiated by the PRC, which placed national reunification at the top of its twentieth-century agenda and established a politburo-level Taiwan Affairs Leading Small Group in 1979 to coordinate the effort.

Trade took off dramatically and investment followed, drawing in still more trade; some industries were attracted by promised access to the China market, while others used China's cheap labor pool to manufacture for export, exploiting the price advantage afforded by China's cheap currency. The Taiwan Strait crisis of 1995-96 
had a temporary dampening effect (some capital flight and, between July 1995 and March 1996, a loss to Taiwan's stock market of nearly 30 percent of its value), but trade continued to thrive, a trend Lee's government sought to counter with his "go south" and "go slow" (jieji yongren) initiatives. But economic headwinds elsewhere (the 1997-99 Asian financial crisis, followed in 2000 by the global high-tech recession) propelled Taiwan capitalists (taishang) back to the mainland. Not even the election of former "Taiwan independence" (taidu) firebrand Chen Shui-bian of the DPP in 2000 had a noticeable adverse impact on cross-Strait relations. The mainland of course did not attempt to discourage trade or investment, but it did try to extort political concessions by demanding a halt to "splittist" tendencies, most forcibly in 1995-96 but again in 2000 and 2004. There were also some Chinese attempts to blackmail prominent proindependence Taiwanese investors like Hsu Wen-long into disavowing DPP support. But for the most part China avoided politicizing an economic relationship from which it also benefited.

Business thus continued to grow in politically good times and bad. By 2014, over 40 percent of Taiwan's trade was with the mainland, and some 80 percent of its foreign direct investment (FDI) went there; Taiwanese businesses operated more than one hundred thousand enterprises on the mainland. The trade balance has consistently been in Taiwan's favor. The upshot after a decade of antiChina Taiwanese political leadership was a widening gulf between economic and political trajectories. The DPP, deprived of official contacts with the mainland, proceeded to "de-Sinify" official political culture and build Taiwanese nationalism by invoking Chinese threats and utilizing "soft power"-reorienting educational curricula, renaming holidays, constructing museums and monuments-and the percentage of Taiwanese who favored reunification either immediately or eventually reached a historical nadir of around 10 percent in 2012. But meanwhile, Beijing demonstrated the power to choke the island's economic and diplomatic lifelines and deter other countries from offering military support. Economic interdependence continued to grow despite official DPP disfavor.

Beijing learned from its experience. After the narrow reelection of Chen in March 2004, Beijing revised its blanket no-contact policy by mixing "harder sticks and sweeter carrots." In his May 17, 2004, statement, Hu Jintao made overtures to Taipei on resuming negotiations for the "three links," reducing misunderstandings, and increasing consultation. In March 2005, the Anti- Secession Law (ASL) was unanimously passed by the National People's Congress, authorizing "nonpeaceful means" in response to a declaration of formal independence in Taiwan. Yet the ASL prohibited "secession" rather than demanding reunification and set no deadline for talks. It also for the first time authoritatively committed Beijing to negotiations on the basis of equal status between the two sides and revised its demand for "one China" as a precondition for talks (quietly disclosing that the 1992 Consensus would be an acceptable interpretation of "one China"). The Chinese 
Communist Party (CCP) also initiated contacts on a party-to-party basis with the opposition, welcoming "pan-Blue" (KMT and People First Party) leaders to the mainland in 2005 and convoking the CCP-KMT Forum, an obvious revival of the United Front, which had historically worked to facilitate cooperation despite ideological contradictions. And when Chen Shui-bian resumed his drive for independence by "freezing" the National Unification Council and National Unification Guidelines in early 2006, Beijing expressed opposition but avoided threats of force, inducing the United States to rebuke Chen for violating the "five nos" that he had promised after his election in 2000 and again in 2004 (no declaration of independence; no change in the ROC's name; no "state-to-state description in the constitution"; no referendum to change the status quo; no abolition of the National Unification Council or the Guidelines for National Unification). By thus lowering the temperature of cross-Strait relations and depriving the DPP of a mainland threat to inveigh against, Beijing contributed to the KMT's landslide victory in both legislative and presidential elections in 2008.

Ma Ying-jeou's response to Beijing's new Taiwan policy was diplomatically positive but domestically more low-key, cognizant of the drift since the early 1990s of domestic public opinion away from reunification. Ma sought to halt the identity battle and shift popular attention to the government's economic performance. His strategy was to skirt "future nation preference" issues, court the middle-ofthe-road voter who cared less about the name of the country than concrete performance, and count on the pan-Blues as captive voters. Thus Ma attempted to redefine Taiwan's politics by shifting its main cleavage from national identity to the economy. The corruption case against Chen Shui-bian was a late-breaking windfall for the KMT that underscored its accusations of DPP managerial incompetence.

After the KMT's 2008 landslide victory in both legislative and executive elections, the new Ma administration lost no time pursuing reconciliation with the mainland along the lines already anticipated in the 2005 pan-Blue visits to the mainland, justifying this departure from his campaign rhetoric by arguing that improved cross-Strait relations would dramatically improve the island's economy. In his inaugural speech, Ma issued "three nos"-no unification, no independence, no war (butong, budu, buwu) - to reassure the electorate, maintaining a discreet silence about the ultimate destination of cross-Strait rapprochement beyond a peaceful and prosperous working relationship. He would move from the easy to the hard, from economic issues to political issues, anticipating a future (repeatedly postponed) discussion of a cross-Strait peace treaty. The cap was lifted on Taiwanese trade and investment with the mainland, and Chinese investment on Taiwan was for the first time permitted. The SEF-ARATS negotiating forum was reconvened, alternating visits between Beijing and Taipei, and by December 15, 2008, the two sides had formally institutionalized "three direct links," facilitating Chinese tourist visits of nearly two million people in the first two years. The SEF 
and ARATS were reconvened and held many sessions, resulting in some twentythree cross-Strait agreements, culminating in the summer of 2010 in an Economic Cooperation Framework Agreement (ECFA), which reduced bilateral trade barriers and cleared the way for Taiwan to negotiate preferential trade agreements with various Southeast Asian countries.

After winning a second term in 2012 by a comfortable if less impressive margin, the Ma administration launched a "re-Sinification" campaign to revive domestic support for the ROC and associated Nationalist symbolism, as Jean-Pierre Cabestan describes in chapter 3. Foreign policy continued to prioritize cross-Strait relations: Ma negotiated the next stage of economic integration, the Cross-Strait Service Trade Agreement (CSTA), while distancing himself from earlier discussion of a peace treaty or political talks. The CSTA was waylaid by procedural opposition and apparent intraparty factional opposition to Ma in Taiwan's legislature, and was finally in effect blocked by the student-led Sunflower Movement, which occupied the legislature in March 2014. Political talks, Ma stipulated, would be contingent on Chinese confidence-building steps, which were not forthcoming. By the end of 2014, the PLA had over 1,500 ballistic and cruise missiles targeting Taiwan, ten times more than in 2000, more accurate and destructive than those launched in the Strait crisis. Ma repeatedly called on the PRC to dismantle this arsenal, most recently at the December 2015 Singapore summit, to no avail. Meanwhile Taiwan's own arms spending lagged, and Ma's election promise to boost it to 3 percent of GDP remained unfulfilled-defense expenditures have continued to decline as a percentage of Taiwan's budget. The United States remained the only actor with a strategic commitment to defend Taiwan, but that commitment was made more "ambiguous" by China's weapons acquisition program, which focused on advanced A2AD (Anti-Access Area Denial) weapons designed to deter US forces from approaching the Strait. Beijing also objected to other countries' sales to Taiwan of weapons designed to redress the defense gap as interference in China's internal affairs. And US arms sales to Taiwan have declined over time. Meanwhile, though Ma had attempted to change the subject domestically from cross-Strait relations to economic growth, the underlying assumption that the former was sure to spur the latter proved overoptimistic. After a spectacular growth spurt in 2010, Taiwan's economy stagnated.

In the presidential and legislative elections in 2016, the KMT suffered a comprehensive defeat. President Tsai Ing-wen took 56 percent of the vote, and her DPP won 68 of 113 seats in the legislature, its first-ever majority. The CSTA and the subsequent Trade in Goods Agreement languished, with only a faint chance of passing in the now DPP-controlled legislature. While President Tsai Ing-wen has promised to preserve mutually beneficial relations with the mainland, she has refused to endorse the 1992 Consensus that Beijing stipulates as prerequisite to talks. Beijing is deeply suspicious of Tsai as the rumored author of the "two states" formula that 
Lee Teng-hui articulated in 1999 (the framing of PRC-ROC relations as "state-tostate relations") and as chair of the Mainland Affairs Commission (MAC) at the time of Chen's 2001 formulation of "one country on each side" (of the Strait; that is, the idea that Taiwan and mainland China are two different countries rather than two political entities within the larger nation of China). Since Tsai's May 2016 inauguration diplomatic contacts have been cut and tourist trade has declined drastically. But the Chinese leadership has refrained from threats of violence, and economic integration continues without political interference.

\section{HEADWAY AND BLOWBACK}

Beijing has always preferred reunification on its terms, of course, either by continuing a civil war to military victory (before Korea) or by making a deal with Taiwan's presumably homesick mainland-exiled KMT elite. When those prospects disappeared with the passing of Taiwan's first-generation leadership, Beijing constructed a path-dependent strategy to assimilate the island peaceably. Taiwan would gradually be enveloped in a web of socioeconomic ties; meanwhile Beijing would cut off its lifelines to the rest of the world by preconditioning all diplomatic relations on denial of the island's legal existence except as part of "China." Trade relations are less amenable to political control than diplomatic, but by entering the expanding regulatory tangle, or "noodle bowl," of Asian free trade agreements and making its own trade contingent on denial of Taiwan's membership China could place Taiwan at an economic disadvantage as well. The three essential components of the strategy were (1) contingent use of force, (2) socioeconomic convergence, and (3) asymmetry in political power. Why has this strategy failed?

First of all, the division between China and Taiwan was born in war, and force has remained an inescapable contingency for resolving the impasse. For many years the mainland threatened "armed liberation" (wuli jiefang) of the island, and it has never renounced the option of force, while the Nationalist regime has launched U-2 surveillance flights and occasional raids in pursuit of its dream to "recover the mainland." In the early 1990s Taiwan renounced the use of force to recover the mainland with a statement that it did not actively challenge Chinese sovereignty over the mainland but only over Taiwan and adjoining offshore islands. The mainland never reciprocated this acknowledgment, insisting on sovereignty over Taiwan under a one-China principle (that there is only one China, that only the PRC represents China, and that Taiwan is a part of that China) and on the "right" to use force (including nuclear weapons) to uphold it, ironically even persuading Taipei to rescind its own disclaimer of mainland sovereignty in 2008 to accord with China's “one-China principle." Beijing has focused its contingency planning with regard to force on a swift and decapitating fait accompli precluding escalation or outside intervention. ${ }^{2}$ To achieve this would require both 
amphibious superiority to win a local offensive war and sufficient regional naval and air capability to deter great-power intervention. China believes it has progressed with the former, making US intervention much more costly than in 1996, and with the acquisition of mobile intercontinental ballistic missiles (ICBMs) and MIRV (multiple independently retargeted vehicle) capability and with submarinelaunched missiles (SLBMs), China boasts a credible deterrent against US nuclear blackmail. Though Beijing has not been engaged in military operations since 1979, it is quite aware of the costs of war, which it would certainly prefer to avoid with the United States, but Beijing has a stronger commitment to unification than the US commitment to prevent it and could use this to deter US intervention. If it comes to a second missile crisis, will the United States send aircraft carriers to the Strait if they can be knocked out by Chinese antiship ballistic missiles? If the United States calculates that Taiwan's autonomy is not worth the cost, and if Taiwan's military forces are clearly inferior to those arrayed against them, China can impose its will on the island without firing a shot.

Yet this scenario, premised on unquestioned local superiority, contains risks China is not yet willing to run. Until then, Beijing's use of force via coercive diplomacy is apt to prove counterproductive because of the democratic blowback to the use of insufficient force. Force can be a successful means of reunification if it is decisive, as in the 1975 Vietnamese reunification. If force is not decisive, as in the Korean War or the 1995-96 Taiwan Strait crisis, it merely antagonizes the opponent and forfeits credibility. Yet Beijing still deems threats of force essential to deter movement toward formal independence and to signal its continuing commitment to reunification. Otherwise Beijing seems to have erased force from its public repertoire, shifting from sticks to carrots and the "boxing in" strategy described by Jing Huang in chapter 13 of this book. But Taiwan realizes that the public downplaying of threats that might discredit Beijing's charm offensive does not mean the weapons are no longer there. This is a dilemma for Beijing: force cannot be used, yet Beijing cannot give up the threat to use it.

Reunification necessarily involves more than the two parts of the divided nation. Even after the end of the Cold War, "great powers" have tended to see their interests at stake in any alteration of the status quo and to intervene. Great-power intervention by the United States has since 1950 been a perennial obstacle to reunification efforts. The United States abandoned Taiwan to embrace China in the early 1970 s in a "strategic triangular" move against the USSR. Since the latter's dissolution in 1991, Washington, hoping to retain leverage with both sides, has attempted to shift its role from supporter to impartial referee, stipulating that the two decide the issue either way so long as they disavow the use of force. Hegemonic intervention, as the United States construes the post-Cold War rules of the game, contains two contradictory imperatives. One has been to maintain the peace, and the other has been to block changes in the territorial status quo that 
are adverse to the hegemon's strategic interests. Preserving the peace is necessary in an era of globalization because wars are unpredictable and at best disrupt gainful economic intercourse. On this objective both sides can agree. But unification under Beijing's auspices, even if peaceful, may shift the regional power balance against American strategic interests. ${ }^{3}$ American China policy has striven to resolve this contradiction. Having declared its principled commitment to neutrality in the three Sino-American communiqués that it signed with the PRC, the United States becomes actively engaged in the reunification issue only when the two sides are on the verge of hostilities-because if war breaks out it is informally committed to fight China, something it would prefer not to do. Thus in the early Strait crises it limited its involvement to defensive moves, not following up after blocking China's moves against the offshore islands and refusing to authorize Chiang's proposal to invade the mainland during the post-Leap disaster.

The continuing counterbalancing role of the United States, as symbolized after derecognition by arms sales to Taiwan, has nonetheless deeply aggrieved the PRC, which is convinced that reunification on terms favorable to the mainland would otherwise be quickly achieved. Beijing prefers to define the issue in purely "domestic" (i.e., bilateral) terms, defining the United States out of the equation. Though the US “one-China” policy formally constrains the United States to accept peaceful reunification even if that is against the US national interest, Beijing has a reasonable suspicion that US support emboldens advocates of the "China threat theory" in Taiwan to resist reunification. As Chen, Kastner, and Reed have pointed out in this volume, this may well be mistaken, and it would in any event be risky to act on such assumptions. Nevertheless, if Beijing and Taiwan both believe that US arms sales have this steeling effect they will tend to inhibit reunification based on force-at least until the balance of power shifts.

In sum, when it comes to force, China is for the time being powerful but frustrated. The PLA at long last is gaining local military superiority over Taiwan. But if it tries to use force to take Taiwan or threatens to do so, it risks triggering US intervention. Unless China can prevent such intervention, a confrontation would result either in asymmetric war or in an embarrassing climb-down and would tend to discredit Chinese threats, as in 1996. Thus the United States is key: China must have local superiority over intervening US forces, plus a sufficiently robust deterrent to inhibit nuclear blackmail if it chooses to use that local capability (for example, by sinking an American aircraft carrier). Chinese objections to US weapons sales are hence somewhat misplaced. What China really needs from the United States is a promise not to intervene in case it uses force across the Strait, but for China to request that would discredit its peaceful reunification intentions and would incur blowback from Taiwan.

Second, under Mao, China represented a revolutionary rejection of both Chinese traditional culture and Western bourgeois values, sharply divergent from 
a Taiwan that viewed itself as the last bastion of Confucian civilization. After the advent of "reform and opening," the CCP leadership under Deng Xiaoping espoused "emancipation of the mind", a more pragmatic attitude to the capitalist world that involved attempting to introduce more efficient economic, technoscientific, and cultural practices from more advanced countries. These innovations were successful in accelerating economic modernization but were socially and environmentally disruptive. Tiananmen was just the largest and most celebrated of the demonstrations that roiled China through the 1980s. China emerged from the Tiananmen incident and the collapse of the communist bloc with its ideological confidence severely shaken. The leadership was in a quandary for the next two years, as some rose to the defense of prereform ideological formulas blaming the Western bourgeoisie for "peaceful evolution," while surviving reformers came under a cloud for having licensed the protests.

Not until Deng's 1992 "voyage to the south" in defense of continuing economic reform was the impasse broken: China would quietly shelve further political experimentation and adopt the Singapore compact of political authoritarianism and economic eclecticism, bringing Zhu Rongji up from Shanghai (initially as vice-premier) to staunch inflation, prepare China for entry into the World Trade Organization, and restructure banks and state-owned enterprises in accord with international "best practices." This proved to be a winning formula, and for the next two decades China experienced a sustained economic boom rarely seen in world history, unavoidably accompanied by a modernizing urban middleclass subculture increasingly convergent with that of other emerging industrial economies-including Taiwan.

Meanwhile Taiwan emerged from the Cold War to dismantle the Nationalist martial law regime and organize democratic capitalism. Economically exportoriented growth was sustained while pushing manufacturing up the value chain into computer peripherals and information technology in collaboration with Silicon Valley. When Taiwanese entrepreneurs ventured across the Strait in the early 1990s, they were welcomed by growth-obsessed local elites, a cheap and capable labor force that spoke the same language (even the same dialect), and a receptive domestic market and/or export opportunities. Taiwan did not join in the postTiananmen sanctions imposed by the Organisation for Economic Co-operation and Development countries after Tiananmen; it even lobbied the United States to end them. As economic growth boomed on both sides of the Strait, the mutual advantages of economic and cultural complementarity became obvious, and Taiwan's economic elites began to set up factories and resettle on the mainland. China became Taiwan's largest trade and investment partner. Over two million Taiwanese have settled on the mainland, where they have careers, families, business associations, schools, and comfortable lifestyles. A recent survey reported that nearly one-third of Taiwanese under age forty hoped to find a job in China 
because of potentially higher salaries and greater room for career advancement. Under ECFA, millions of Chinese tourists, thousands of Chinese permanent residents (mostly spouses of Taiwanese), and some Chinese business ventures have been established on the island. With the mainland's revival of traditional values ("harmonious society"), even cultures have begun to converge.

But social assimilation has had only limited political impact, Shu Keng and Emmy Ruihua Lin report (chapter 4), increasing "Blue" and decreasing "Green" (DPP coalition) votes and compatible business practices but exerting no noticeable effect on Taiwanese national identity, which has become firmly established on both sides of the Strait. Voting is one thing, but there is as yet no sign of prounification advocacy by taishang among the island's ruling elites. And the ideological convergence witnessed under the pragmatic Deng Xiaoping has clearly diminished under Xi Jinping.

Why does politics remain an outlier? The basic motive force of convergence has been economic. For twenty years China's double-digit growth was irresistible to Taiwan business. The global financial crisis that struck in 2008 made Taiwan more economically dependent on China by cutting export demand elsewhere, which seemed fortuitous at the time, as China introduced a huge stimulus package in 2009 that helped salvage Taiwan as well. But after a big GDP upsurge to 10.8 percent in 2010, Taiwan's growth declined. ${ }^{4}$ Though there is a widespread impression in Taiwan that inequality also increased, careful examination of available statistics shows this claim to be ill-founded. ${ }^{5}$ Over 60 percent of Taiwan's economy is dependent on exports, and China and Hong Kong are Taiwan's biggest trade partners, but Taiwan's exports have been very choppy since plunging deeply in 2009, sinking into negative territory again in 2015. Part of this can be attributed to the steady annual decline of China's GDP growth since 2010. But why has the drop been more precipitous in Taiwan? At least one reason is the effort since 2009 to move Chinese industry up to a higher value-added, technology-intensive niche, in effect squeezing out Taiwan industries (whether in Taiwan or on the mainland) in favor of a "red supply chain" of Chinese manufacturers, as Tse-Kang Leng makes clear in chapter 9.

Meanwhile the cumulative impact of outsourcing has been a decline of employment opportunities in Taiwan. Aggregate employment statistics actually show an upswing, from 5.2 percent unemployment in 2010 to 3.79 in 2015 . But youth unemployment has been hovering at around 12 to 13 percent, reaching a high of 14.02 percent in August 2014. Taiwan's youth thus backed the 2014 Sunflower Movement and voted overwhelmingly DPP in 2016. Taiwan has entertained only a fraction of Hong Kong's mainland tourists (3.4 million in 2015 vs. Hong Kong's 47 million), but the sudden influx has been felt: they have high per capita incomes and have injected some US $\$ 200$ billion per annum into the economy. But they arouse familiar complaints: they are described as a loud, uncouth lot whose spendthrift ways drive 
up prices. The KMT's attempt in the CSTA to open Taiwan's economy to mainland investment, though a potential economic boom, excited fears of a "Trojan Horse" in the form of Chinese purchase of mass media and high-tech firms.

In sum, economic convergence has indeed brought the two sides closer together, but it has also driven up expectations faster than they could realistically be fulfilled and has included unanticipated externalities. Meanwhile, the decisive economic variable is not convergence but growth, which has declined on both sides of the Strait for the first sustained period since détente took off in the early 1990s. It turns out to be risky to base reunification so narrowly on an everlasting economic boom.

Third, power symmetry across the Strait has changed over time, and this has affected the reunification dynamic. The stronger side has greater incentive (and resources) to assume a leadership role in the reunification process, assuming it will dominate the reunified state. One big problem is that the response of the weaker side to asymmetry has been to lose interest in political unification. Thus Ma Yingjeou retreated from his early proposal for a cross-Strait peace treaty and repeatedly postponed initiation of political talks. The logic of asymmetry implies that the stronger state must be exceedingly gentle in order to build the confidence of a weaker counterpart facing greater risks. Yet this runs counter to the human tendency for the strong to exploit their advantage and humble the weak. Given this human propensity and suspicions of what Mao called "sugar-coated bullets" even when terms seem more generous, the best time for plausible reunification proposals has been during periods of relative symmetry. The most auspicious of these was in the early 1990s, viewed retrospectively by KMT elites as a golden era (dianfeng shiqi). On both sides there was a spirit of emancipation: Taiwan from the Chiangs' dictatorship, China from Mao's fitful tyranny and the Cultural Revolution. The Cold War structures had collapsed; it was a new world. On both sides there was greater willingness to open-mindedly experiment. "China fever" (dalu re) brought renewed human contact and the informal realization of Beijing's "three links." Despite its small size and population, at the time Taiwan's economy was nearly half as big as China's and more technologically advanced; from a security perspective the island still had a qualitative edge sufficient to deter any threat of invasion without US intervention.

Today the power balance has changed momentously. While in 1990 China's GDP was only 2.4 times that of Taiwan, by 2010 it was 13.7 times as large. Trade interdependency has become asymmetrical in the sense that Taiwan has proportionately more to lose than the mainland. China is Taiwan's biggest trade partner, but Taiwan is only China's fifth-largest trade partner. While 80 percent of Taiwan's FDI goes to the mainland (up from 50 percent in 2003), only a tiny fraction of China's FDI goes to Taiwan, because of the latter's reservations. 
In terms of military power the asymmetry is even more striking, partly because even a small proportion of the world's second-largest economy is a very substantial arms budget, partly because the PRC has successfully dissuaded many other countries from selling arms to Taiwan. Beijing's military budget has risen eight-fold in the last twenty years, according to the Stockholm International Peace Research Institute, reaching 10 percent of global arms spending in 2012. Beijing has grown confident of its ability to defeat Taiwan quickly in a bilateral war. Diplomatically Beijing officially granted Taipei equal status in 2005, but this is valid only bilaterally; internationally Beijing colludes with others to ostracize Taiwan except as "Taipei, China," or "Chinese Taipei."

Notwithstanding its growing superiority, the PRC has attempted to maintain bilateral noblesse oblige, offering not only a high degree of autonomy in future reunification arrangements but generous trade packages and fostering many exchange arrangements. During the period of rapprochement Beijing's generosity extended to a sincere (if very limited) diplomatic truce. None of these are more than time-bound accommodations, however, as Taiwan's narrowing diplomatic space in the Tsai era has since demonstrated. And the gap between generous bilateral policy and continuing international ostracism, not to mention tightening domestic constraints on civic freedom amid a crackdown on dissent, tends to inspire skepticism about purpose-rational bilateral concessions. China's economic miracle, taking it far past Taiwan economically and promising to overtake it with regard to technology and eventually living standards as well, has made it a proud giant reluctant to expand upon the generous "one country, two systems" formula offered under Deng in the early 1980 os. The only concession since has been the "differing interpretations" addendum to "one China" granted in 1992, which Xi Jinping would now like to take away. Hong Kong's recent experience has not encouraged faith in Taiwan's future as part of China.

\section{CONCLUSION}

The China-Taiwan relationship, highly volatile from the beginning, has changed greatly since the advent of democracy in Taiwan and reform and opening in China, but it remains volatile just the same. For a time it seemed that a troubled relationship that has resisted all military and diplomatic solutions might be resolved by mutual interests. But that bubble of hope has now also popped. Whether economic interests could have continued to integrate the two sides of the Strait is doubtful in any case, but now the economic engine is decelerating. Although it has failed to bring about reunion, there is little space for reaction in the other direction. Beijing still clings to the dream. Even on the (highly unlikely) chance that Beijing will overlook a declaration of formal independence, geographic, sociocultural, and 
economic ties are now too tightly bound to permit the island to go far from Beijing's embrace.

What are the main reasons for the waning of the dream? Surely the threatened use of force remains among them. This is now more or less exclusively wielded by Beijing, though reciprocal military exercises and an arms race continue. China reserves its right to use force and may in due course feel strong and bold enough to do so. Yet some progress has been made. Both sides have agreed that peaceful reunification, preceded by economic integration, is a better solution for both than the use of force. Beijing has learned that the use of force is politically counterproductive unless wielded in a decisive blow, making that option less likely and more risky. Greatpower intervention has diminished over time as the absence of crises has made it unnecessary. Neither arms sales to Taiwan nor the military buildup on the Fujian coast has ceased, but there seems to have been a tacit understanding since the Strait Crisis that as Chinese threats and crises diminish, American arms sales will avoid destabilizing the balance: hence no submarines, no fifth-generation stealth fighters. It would be better if the threat of force could be completely removed from the picture, but that would require more trust than is currently at hand. Even without trust, given a protracted hiatus in the actual use of force (i.e., no crises), the probability of its invocation may tacitly diminish over time.

One of the biggest changes has been socioeconomic convergence. Though to some extent inhibited by Taiwanese "self-ghettoization" in homogeneous communities and mainlander discrimination, there is no language barrier, and there has been considerable intermixing on both sides of the Strait. Mutual understanding does not necessarily entail mutual affinity or political agreement, and socioeconomic convergence has not yet led to perceptible progress toward changes of national identity. This may have to await future generations, assuming continuing intermarriage between Taiwanese and Chinese. National identity may be last to change. Before that may come voting patterns, the buildup of vested interests, and finally some political concessions on both sides. For attitudes truly to change it would also be useful to have honest political discussions, which is difficult at present, particularly on the mainland. It will be a long process.

There is also the problem of relative gains. While reunification would be good (an absolute gain) for both sides and beneficial to the international community, it might be better for one side than the other. Specifically, it is better for the stronger power than for the weaker. A rational stronger power tends to minimize concessions and push for simple annexation while making minimal changes in the domestic status quo (as in the German case). This enhances domestic support for the process but motivates the weaker power to resist. The Taiwan-China relationship has become steeply asymmetrical, and to extrapolate current growth rates this is apt to increase, heightening Taiwan's disincentive to move toward unification. It will require great sensitivity on the part of the dominant party to reassure the 
weaker. Hence China offers "early harvest" and other concessions to Taiwan as "loss leaders" to encourage economic integration. The taishang respond as "free riders," gladly accepting all concessions. This leads to increasing economic integration, but whether the Taiwanese become more politically committed to the PRC is unclear. This is frustrating to the giver of the concession, who cannot however accuse the receiver of bad faith because the political quid pro quo was never explicit. To make it explicit would encumber Beijing's "no-strings-attached" and "win-win" trust-building model with political quid pro quos. Thus we have fragile sociocultural integration without much political payoff, at least in the short run.

Growing asymmetry has become perhaps the most unexpected obstacle to reunification. In itself the Chinese economic miracle is an epochal achievement. One of its motives was to surpass Taiwan, on the assumption that once China was in a position of undisputed superiority all resistance would surely collapse. Economic growth also incentivized "win-win" cross-Strait socioeconomic integration. Yet the same economic miracle that boosted the Chinese (aggregate) economy well past that of Taiwan and made the PLA Asia's largest military has also constructed a party-state juggernaut that has become a threat to any who stand in its way. To be fair, Beijing has since 2005 leaned over backward to court Taiwan with sundry concessions. But all this is not enough. The world's second-largest economy, which now aspires to become a global "pole" commanding its own strategic periphery and integrating Eurasia with ports and high-speed rail, sees no need to restructure its party-state to reassure a reincorporated Taiwan of any real influence in governing greater China. Taiwan is small and China is big, to parody Yang Jiechi. The Taiwanese have been able to descry the difference between economic convergence and political assimilation and to accept the former while evading the latter. The Xi Jinping leadership looks askance at this and is disinclined to let it continue. What they can do to stop it without unacceptable damage to their own economy and international reputation remains to be seen.

In sum, in view of recent developments the route to a mutually acceptable arrangement for divided sovereignty may yet be a long and bumpy one. Taiwan may never fully break out of Beijing's comprehensive geo-economic "boxing in" strategy. But Beijing may also not succeed in peacefully integrating the long-separate island nation into its vision of an ideologically homogeneous "one China."

\section{NOTES}

1. Actually, Germany and Korea were divided by the victors in the aftermath of World War II, and China was divided by a civil war immediately after World War II; only Vietnam was divided during the Cold War. But in all cases the basis of cleavage was the ideological split between capitalism and communism that defined the Cold War.

2. See Steve Tsang, If China Attacks Taiwan: Military Strategy, Politics and Economics (New York: Routledge, 2006). 
3. There is an interesting ambiguity about this. On the one hand, the United States no longer recognizes or has an alliance with Taiwan, and its declaratory policy is neutral about peaceful reunification. China has promised as part of its "one country, two systems" approach not to station troops and to permit the island's continued strategic autonomy. On the other hand, the Chinese have never spelled out how Taiwan's military would continue to function autonomously or what its future relation to the PLA would be, and they clearly consider Taiwan a key link in the "first island chain." See Alan M. Wachman, Why Taiwan? Geostrategic Rationales for China's Territorial Integrity (Stanford, CA: Stanford University Press, 2007), 208n119.

4. In 2008 Taiwan's GDP was 1.8 percent, plunging to -1.9 percent in the aftermath of the global financial crisis in 2009, resurging to 10.8 percent in 2010, then declining to 4 percent in 2011, 1.5 percent in 2012, 2.1 percent in 2013, 3.5 percent in 2014, 0.7 percent in 2015, and 1.5 percent in 2016. The average annual growth rate from 1962 to 2015 was 7.01 percent, so this obviously represented a decline from the perceived "normal" and was lower than Taiwan's "Small Tiger" reference group (South Korea, Hong Kong, and Singapore).

5. Taiwan's Gini index of inequality is relatively low among developed economies (and far lower than China's). It has indeed increased along with globalization, from .28 in 2008 to .34 in 2015, but the rate of increase is no higher than in previous decades and is not statistically significant. 